\title{
COMPUTER SERVICES AND THE FEDERAL REGULATION OF COMMUNICATIONS
}

The linkage of widely separated locations to a central data mass or message-switching control has entailed a growing dependence upon communication networks by data processing services. At the same time, the major communication carriers are employing digital computer systems to provide faster, more efficient service. ${ }^{1}$ It is estimated that more than sixty per cent of the computer hardware used in the United States will be tied into the public communication systems by $1975^{2}$ and as much as ninety per cent by $1984 .^{3}$

The resultant increased availability of computer services will make many new conveniences available to the consumer. These advantages, however, tend to overshadow the serious problems of regulatory policy which necessarily will arise. The immediate problem is clear - the current regulations governing the communications industry are inadequate to deal with the interaction of the two services, while to the communications carriers, such computer services seem a natural adjunct which they should be able to offer in combination with existing communication services. The problem is further exacerbated by the fact that the carriers are regulated under the Communications Act of $1934,{ }^{4}$ while the data processing and services utilizing the modern digital computer thus far remain unregulated. Recognizing the inevitable significance of these problems for federal regulatory policy, the Federal Communications Commission, in November, 1966, published a notice of inquiry requesting comments and suggestions on the interdependence of computers and communication services and facilities. ${ }^{5}$

As one response to that notice of inquiry, this Comment unfortunately is limited by the present lack of empirical data necessary to reach confident conclusions on some of the policy issues presented. It is hoped, however, that its legal as opposed to factual or economic approach may help channel any future factual investigation as well as outline possible alternatives open to the FCC.

1 Irwin, The Computer Utility: Competition or Regulation?, 76 YALE L.J. 1299, 1301-02 (1967); Pierce, The Transmission of Computer Data, ScIEntific AMarican, Sept. 1966, at 145 .

2 Address by Bernard Strassburg, Chief, Common Carrier Bureau of the FCC, The Communications Carriers and Management Information Systems, before the Institute on Management Information and Data Transfer Systems, at American University, Washington, D.C., Oct. 21, 1965.

3 Letter from Mr. Walter Bauer, President, Informatics, Inc. to Mr. Ben F. Waple, Secretary, Federal Communications Commission, Dec. 9, 1966.

447 U.S.C. $\$ \$ 151-609$ (1964).

5 In re Regulatory and Policy Problems Presented by the Interdependence of Computer and Communication Services and Facilities, FCC Notice of Inquiry, FCC 66-1004, Dkt. 16,979, 8 P \& F RAdro REg. 2d 1567-68 (Nov. 9, 1966). 


\section{The Bunker-Ramo Controversy}

The FCC investigation was sparked by a dispute between Western Union, a communications common carrier subject to federal regulation, and Bunker-Ramo Corporation, one of three firms offering an "on line-real time" stock quotation service to the financial community over the private long-line wires of Western Union and other communication common carriers. Western Union refused to provide private long-line service for Bunker-Ramo's proposed Telequote IV service, a data processing and message-switching service adding to the capabilities of Telequote III, the basic quotation service. ${ }^{6}$

The basic Telequote III offering operates through arrangements with the New York and other stock exchanges. Information concerning listed securities is gathered, constantly updated and stored on regionally located magnetic memory drums in Bunker-Ramo computers. A broker, by dialing the Bunker-Ramo computer, can instantaneously obtain data regarding last price sold, last price offered and so forth for any of the stocks traded on the exchanges. Telequote IV was designed to add a message-switching capacity, by means of which the various offices of subscribing brokerage firms could communicate with each other. Telequote IV would permit a buy or sell order from a particular branch office of a broker to be sent to and stored in a regional computer until polled by a central computer, checked for parity and forwarded to the broker's office or to the broker's representative on the floor of the exchange. Execution orders would be routed back to the branch office from which they originated in similar fashion. ${ }^{7}$ In addition to this message-switching service, Telequote IV was to afford information storage and processing services with respect to margin accounts and financial research. ${ }^{8}$ The computers were to be programmed so as not to allow any information except that specifically provided for in the Telequote III or IV proposals to be sent over the private lines. ${ }^{8}$

6 For communications relating to the Bunker-Ramo dispute, see Letter from Arnold, Fortas \& Porter to Bunker-Ramo Corporation, March 12, 1965; Letter from Arnold, Fortas \& Porter to Honorable William Henry, Commissioner, Federal Communications Commission, Aug. 29, 1965; Letter from Arnold, Fortas \& Porter to Bunker-Ramo Corporation, Aug. 29, 1965; Letter from American Telephone \& Telegraph Co. to Mr. Ben F. Waple, Secretary, Federal Communications Commission, Sept. 29, 1965; Letter from Western Union Telegraph Co. to Mr. Ben F. Waple, Dec. 3, 1965; Letter from Grove, Paglin, Jaskewicz, Gillian \& Putbriese to Mr. Ben F. Waple, Jan. 17, 1966; Letter from Arnold \& Porter to Mr. Walter B. Kelley, Assistant Vice-President, American Telephone \& Telegraph Co., Feb. 4, 1966; Letter from Mr. Walter B. Kelley to Arnold \& Porter, Feb. 16, 1966.

7 This description is taken from a memorandum on the functions performed in the Telequote IV System, accompanying Letter from Arnold \& Porter to Mr. Walter B. Kelley, Assistant Vice-President, American Telephone \& Telegraph Co., Feb. 4, 1966.

8 The description of Telequote IV as originally planned is found in Letter from Arnold, Fortas \& Porter to Bunker-Ramo Corporation, March 12, 1965.

9 See Letter from Arnold, Fortas \& Porter to Bunker-Ramo Corporation, Aug. $29,1965$. 
The refusal of Western Union to provide Bunker-Ramo with the private line service required for Telequote IV was concurred in by AT\&T. Two arguments were advanced in support of this position: first, Bunker-Ramo was not entitled to such service under the published tariffs of the carriers; second, should Bunker-Ramo undertake such a service, it would be subject to direct $F C C$ regulation under the Communications Act ${ }^{\mathbf{}}$ as a communications common carrier. The dispute was eventually settled through negotiation, ${ }^{11}$ but in the process several issues which will become increasingly important as data processing services multiply were left undecided.

\section{The Private Line Tariffs of the Common Carriers}

Western Union's primary objection was based on the wording of its published tariff schedule. This schedule, which has the effect of law, ${ }^{12}$ provides, in pertinent part:

§ 3.2. Only the following may be authorized users:

(a) Persons, firms or corporations who are to receive or send communications from or to the customer only and relating solely to the customer's business. ${ }^{13}$

Western Union argued that the messages, sent between brokerage offices and switched by the Bunker-Ramo computers, would be messages "to" one office "from" another for which the computer would be only a conduit. Bunker-Ramo, on the other hand, argued that each message would travel first "to" a Bunker-Ramo computer and then "from" that computer to the broker.

An explanation of the nature of the private line service of the carriers is necessary to place these arguments in proper perspective. As first developed, the private line was a means by which parties carrying on a large amount of specified communication by wire could avoid the use of the general exchange systems offered by the communication carriers and maintain the availability of constant communicating capacity. As described in one early decision:

These lines are not connected to the general exchange system.

The wires used and the instruments attached to them are owned and maintained by the telephone company. The company does not permit telephone instruments not owned by it to be attached to these lines. There is no switching permitted or

1047 U.S.C. $\$ \S 201-22$ (1964).

11 See Letter from Arnold \& Porter to Mr. Walter B. Kelley, Assistant VicePresident, American Telephone \& Telegraph Co., Feb. 4, 1966. AT\&T provided lines for the "modified" Telequote IV service. There is a possibility that this was a result of greater flexibility in the language of the AT\&T tariff. See note 17 infra.

12 See text accompanying notes 20-25 infra.

13 Western Union, Tariff FCC No. 237, original at 17, isstued Mar. 14, 1966, effective April 17, 1966. 
provided for between stations of such a system. Communication may be had between several stations and a central point but the different stations are not connected one with the other. Brokers are said to be the principal users of private line systems. They are used mainly between points where they have a great deal of communication. ${ }^{14}$

Prior to the advent of computerized technology, it appears that the communication-by-voice nature of the private line service changed to permit non-voice communication by wire, while the restrictions upon customer attachments were relaxed sufficiently to permit connection of the data processing input, output and computerized storage facilities to the telephone wires. Other than these changes, the concept of the private wire service appears to have remained constant, explaining to some degree the "from or to" requirement of the carriers' tariffs. The Telequote III offering appears as the modern equivalent of the old brokerage private line arrangement, permitting communications only between the individual brokerage offices and the Bunker-Ramo computers, the latter constituting the central points of the system. The quotation requests are messages which begin in an office, travel only to the computer and return to the original office. Similarly, the computer's job with respect to the information originated on the floor of the exchange about a particular stock is potentially completed when that information is stored in the computer. The communication of this message to a broker depends upon a specific request by the broker and hence is not a necessary part of any communication between the computer and the system of exchanges from which the information originates. In these two instances, then, the messages handled over the private line system can, for practical purposes, be said to be "from or to" the computer. Not explained, however, is the modification of the private line service which permits Bunker-Ramo to constitute, in the person of its computers, the "central points" of the communication systems.

In light of this development of the private line concept, therefore, it is arguable that, as Western Union contended, the transfer of administrative data and of buy and sell orders (the Telequote IV offering) would constitute the handling of communications through the computers of Bunker-Ramo which, in that situation, would resemble the facilities of a regular telephone company.

The strength of this somewhat metaphysical argument has been undercut, however, by AT\&T's acquiescence in the handling by Bunker-Ramo, as part of a modified Telequote IV offering, of the buy and sell orders and the executions of those orders. ${ }^{15}$ This sug-

$14 \operatorname{Re}$ New York Tel. Co., 44 P.U.R. (n.s.) 265, 269-70 (N.Y. Dep't, State Div., Pub. Serv. Comm'n 1942) (emphasis added).

15 Letter from Mr. Walter B. Kelley, Assistant Vice-President, American Telephone \& Telegraph Co. to Arnold \& Porter, Feb. 16, 1966. 
gests, following the earlier analysis, that AT\&T has relaxed its stand against the handling by a customer of messages which by their nature do not end at a Bunker-Ramo computer and, hence, cannot be said to be "from or to" Bunker-Ramo. The description of the process by which buy and sell orders and executions are handled shows that the difference between it and the system which would handle the contested administrative data is slight. The buy and sell orders will be sent to either the central brokerage firm or the floor of the exchange; to this extent, there is a choice of recipient. When executions take place, they will be sent back to the office from which they originated, ${ }^{18}$ a process which will necessitate some means by which to direct them. Thus, there will be, in both directions, a process comparable to message-switching or the switching of message direction. Admittedly, however, the choice of recipient is limited compared to that which would exist under a full message-switching system where authorized users could communicate between any of their offices.

The second element of the tariff requires that a message relate "solely to the customer's business." Although this language is ambiguous, it is arguably inconsistent with the nature of both Telequote III and Telequote IV, which are, by definition, services for the benefit of the brokerage industry, naturally relating to that industry. The messages which involve message-switching, and those which do not, relate to the brokerage business in the same way; both aid the subscriber firms in their brokerage business. The language of the present AT\&T tariff is similar, requiring that messages be to and from the customer and "relate directly to the customer's business." 17 In the present context, this would require a direct relation of every message

16 See memorandum, supra note 7.

17 American Telephone \& Telegraph Co., Tariff FCC No. 260, original at 17, issued March 14, 1966, effective Oct. 16, 1966.

The AT\&T tariff originally required that a message "relate solely to the customer's business." This language was changed to its present form in 1963, over the objections of Scantlin Electronics, Inc., which petitioned the FCC for a suspension of the tariff and a hearing on the changes. American Telephone and Telegraph Co., Tariff No. 134, Petition of Scantlin Electronics, Inc., July 12, 1963. The petition described Scantlin's use of leased private lines to supply computer information, $i d$. at $2-5$, and expressed concern that the change in language would be construed to restrict or prevent the continuation of these services. Id. at 8-9. AT\&T replied that the Scantlin services, as then constituted, would violate neither the existing nor the new tariff. The FCC opinion concluded that "the Commission is of the view that the proposed tariff amendments will not restrict or prevent [Scantlin] from providing the services described . Re American Telephone and Telegraph Company, Tariff No. 134, FCC 63-752, Dkt. 38,399 (August 7, 1963).

The petition also noted, as among the services offered by Scantlin:

Similarly, the computer can be used by [Scantlin's] broker clients to obtain instantaneous calculations of customers margin positions. A branch office can interrogate the computer which in turn will interrogate the head office, determine the content of the customers' portfolio and his current balance, compute buying power on the basis of up-to-date market prices, and transmit the restilt to the interrogating office.

Petition, supra at 3 . This amounts to a message-switching service similar to the original Telequote IV offering, but more limited in scope. 
to the business of data processing, that is, information storage and processing, which by its very nature bears the same relation to every message which it is programmed to handle.

The data processing offering, however, would probably not be prohibited under this "direct relation" test, following the reasoning set forth in Aeronautical Radio, Inc. [ARINC] v. American Tel. \& Tel. Co. ${ }^{18}$ The ARINC case dealt with an application for private wire service by a company licensed by the FCC to coordinate communications relating to air traffic and weather conditions for the purpose of furthering safety in air travel and transport. AT\&T refused to furnish the facilities contending, inter alia, that ARINC would be handling communications in which it had no direct interest, contrary to the tariff restrictions. Although the Commission did not reverse AT\&T's refusal because of a technical flaw in the application, it stated, in disposing of AT\&T's major contention:

It must be concluded that no interest in the content of the messages handled is necessary, but that it is sufficient if the fact that the message is sent aids the lessee in carrying out purposes of its own distinct from those of a common carrier for hire. ${ }^{19}$

Just as every message relating to air safety may be a direct interest of ARINC, so may the messages dealing with stock quotations, buy and sell orders or administrative data bear a "direct relation" to the business of Bunker-Ramo. This "direct relation" language, then, is not in itself sufficient reason to deny carrier facilities to an applicant.

It should be noted, finally, that the tariff language discussed above, while important, may not be determinative of the dispute. Tariffs must be "just and reasonable" ${ }^{20}$ whether they relate simply to charges or to "practices, classifications and regulations." 21 Those which are unjust or unreasonable are unlawful, ${ }^{22}$ and may be challenged upon submission or after FCC approval by either a private party or the FCC. ${ }^{23}$ Where the FCC determines that a tariff is in violation of the Communications Act, it may prescribe practices which it deems "just, fair, and reasonable." ${ }^{24}$ However, until the Commission determines that the tariff is unreasonable, it has the effect of law. ${ }^{25}$

184 F.C.C. 155 (1937).

10 Id. at 164.

2047 U.S.C. $\$ 201$ (b) (1964).

21 Id.

22 Id.

2347 U.S.C. $\$ \$ 204,205$ (a), 208 (1964).

2447 U.S.C. $\$ 205$ (a) (1964).

25 Despite the disparagement of plaintiffs that the tariff is initially the handwork of the Telephone Companies' scriveners and is, at any event, not a rate but a mere equipment tariff, . . . . a tariff, required by law to be filed is not a mere contract. It is the law.

Carter v. American Tel. \& Tel. Co., 365 F.2d 486, 496 (5th Cir. 1966). 


\section{Competition Between Customer and Carrier}

The other tariff provisions raised in the Bunker-Ramo dispute prohibit the use of a private line service for an undertaking "for which a payment or other compensation shall be received by . . . the customer," 26 and empower the carrier to cancel a private line service when it is used "for the purpose of performing any service in competition with the service which the [carrier] . . . may now or hereafter furnish." 27 It is clear that these provisions read more strictly than they are applied. Bunker-Ramo, under Telequote III, is using a private line in a service "for which a payment" is received by it, so to this extent at least the tariff has not been enforced by the carriers.

Some clarification as to the intended scope of these provisions is presented in the ARINC case, in which the Commission noted:

The chief purposes of the restrictions in defendant's tariff rules appear from the brief of defendant to be to prevent the facilities . . . from being used by other common carriers of communications, and to prevent the creation of middlemen competitors between defendant and its customers with a resulting diminution of defendant's revenues and possible discrimination in charges to the public. ${ }^{28}$

Thus, the carrier's basic concern is with those who might attempt to use the carrier facilities to compete in offering communications to the public, forcing the carrier to become a wholesaler of communications which it could "retail" itself.

The extent to which common carriers are to be protected, under the Communications Act, from any economic harm due to competition is unclear. In the recent case of In re Finer Living, Inc. ${ }^{29}$ the FCC faced the problem of whether the existence of common carrier facilities capable of performing the function of a proposed private microwave system precluded the grant of a license to the private applicants. Relying on an earlier report on this question, ${ }^{30}$ the Commission held that the private license could be issued. The report had posed the question of whether the Communications Act, either on its face or by implica-

26 American Telephone \& Telegraph Co., Tariff FCC No. 260, 1st Rev. at 20, issued May 10, 1966, effective June 9, 1966; accord, Western Union, Tariff FCC No. 237, 4th Rev. at 12, issued Sept. 9, 1966, effective Oct. 16, 1966.

27 American Telephone \& Telegraph Co., FCC No. 260, 1st Rev. at 20, issued May 10, 1966, effective June 9, 1966. Accord, Western Union, Tariff FCC No. 237, 2d Rev. at 14, issued June 30, effective Aug. 5, 1966.

28 Aeronautical Radio, Inc. v. American Tel. \& Tel. Co., 4 F.C.C. 155, 165-66 (1937) (emphasis added).

28 8 P \& F Radio Reg. 2d 1160 (1966).

30 In re Allocation of Frequencies in the Bands Above $890 \mathrm{mc}, 18$ P \& F Radro REG. 1767 (1960). 
tion from the "public interest" standard, required the Commission to protect the common carriers from the possible economic harm of private system competition. Finding no express statutory command, the Commission report indicated that:

The touchstone of the Communications Act is not the fostering of competition per se, but rather that course which will best serve the public interest, convenience and necessity. In the application of these criteria, certainly, competition would be one, but not the sole, factor to be considered. ${ }^{31}$

The Finer Living case, however, may not be entirely relevant. First, the FCC was not required to deal with the additional problem of requiring a utility to aid its competitors by allowing resale of its services. The Commission report on the microwave situation did briefly consider, however, whether a carrier could be compelled to connect a private microwave system to its communications network, implying that the costs of establishing such systems and the tariffs themselves would be sufficient to limit competition. ${ }^{32}$ Second, there is a distinction between the "public interest, convenience, and necessity" standard ${ }^{33}$ applicable to licensing of broadcasting stations ${ }^{34}$ and certificates of convenience for the construction of common carriers ${ }^{35}$ and the "just and reasonable" standard applicable to the tariff provisions. ${ }^{36}$ While the former permits consideration of the competitive implications of a particular offering, the latter concentrates on a balancing of customer and carrier interests. In the instant context, any such balancing also should consider the larger interests of the data processing industry.

Furthermore, the tariff issues under consideration should be recognized for what they are: policy questions inextricably related to the broader problem of the conflict between regulated and nonregulated economic entities. A possible approach to this problem is suggested in Philco Corp. v. American Tel. \& Tel. Co. ${ }^{37}$ The court, while denying jurisdiction over a tariff dispute between a television station and a common carrier, said:

[W] hether these [tariff] regulations should be held to be beyond the statutory power of the Telephone Company to adopt may depend upon a consideration of economic relations,

31 Id. at 1788. This was a paraphrase of the Supreme Court's opinion in FCC v, RCA Communications, Inc., 346 U.S. 86 (1953).

3218 P \& F Radio REg. at 1789.

3347 U.S.C. $\$ 309$ (a) (1964).

3447 U.S.C. $\$ 301$ (1964).

3547 U.S.C. $\$ 214$ (a) (1964).

3647 U.S.C. $\$ 201$ (b) (1964).

3780 F. Supp. 397 (E.D. Pa. 1948). 
of facts peculiar to the business or its history, of competitive conditions and other relevant circumstances generally unfamiliar to a judicial tribunal, but well understood by an administrative body especially trained and experienced in the intricate and technical facts and usages in the television communications filed $[\mathrm{sic}]$. $^{38}$

Taking this approach, one must note immediately the basic distinction between the Bunker-Ramo situation and the typical resale case-the mixed nature of the data processing offering. Whereas the usual resale case deals with a clear attempt to retail only communications, the Bunker-Ramo situation involves a communications service which is intimately connected to a non-communications service. The implications of this are significant. Should Western Union, for example, offer a system capable of message-switching, it would be natural to couple this offering with the related stock quotation services. Should Bunker-Ramo be prevented from offering a message-switching service, the common carriers could monopolize this aspect of data processing. The common carrier could be required, of course, to offer the two services separately, but this would not prevent a cost discounting by the carrier in the competitive service which could be made up by higher pricing in the monopolized area. ${ }^{39}$ The resultant package probably would be more attractive to a prospective subscriber than a package consisting of a limited quotation service from the independent firm and a separate message-switching service from the carrier. This advantage would be further enhanced by the carriers' influence over entry into the data processing field ${ }^{40}$ and their ability to withstand substantial losses incurred in price wars. ${ }^{41}$

\section{Telequote IV: A Communications Common Carrier Service?}

Bunker-Ramo's alleged status as a common carrier of communications raised the second main issue in the case, since the tariff language denying service to a competitor was aimed at other common carriers of communications. ${ }^{42}$ If Bunker-Ramo were found to be a common carrier, it would be subject to rate and tariff regulation ${ }^{43}$ and the expenses entailed in complying with financial reporting requirements ${ }^{44}$ and resulting from litigation before regulatory agencies.

$38 \mathrm{Id}$. at 399. This test is derived directly from 47 U.S.C. $\$ 204$ (1964).

39 See Irwin, The Computer Utility: Competition or Regulation?, 76 YALE L.J. 1299, 1305-06, 1308-09 (1967).

$40 I d$. at $1306-08$.

41 Id. at 1310 .

42 See text accompanying note 28 supra. Viewed in this light, $\$ 3.2$ of the Western Union tariff, see text accompanying note 13 supra, can also be seen as an anti-retailing provision.

4347 U.S.C. $\$ 201$ (1964).

4447 U.S.C. $\$ \S 219-20$ (1964). 
Furthermore, it would remain entirely dependent upon the common carriers providing the facilities because the FCC has held that it has no jurisdiction over contracts between common carriers involving the use of each other's facilities, although it has requested legislation to overcome this disability. ${ }^{45}$ Through such contracts the carrier could charge for the use of its facilities in such a way as to discriminate openly in favor of itself, thereby achieving market dominance over the data processing firms. If found not to be a common carrier, Bunker-Ramo, although still subject to the more subtle forms of carrier discrimination, ${ }^{46}$ would have a stronger position on the tariff and open discrimination issues. Thus, although a determination of Bunker-Ramo's legal status does not completely resolve the problems, it does provide a point of departure for further action.

The claim that Bunker-Ramo's Telequote IV service constituted a common carriage offering must be considered within the context of the Communications Act of 1934, passed twenty years before the advent of the computer industry. ${ }^{47}$ This attempt to bring a revolutionary technology within a decades-old statutory framework is bound to prove unsatisfactory, but it must be attempted, if only to determine the areas in which amendatory legislation would be helpful.

The governing statute, section $3(\mathrm{~h})$ of the Communications Act, states: " 'Common carrier' . . . means any person engaged as a common carrier for hire, in interstate or foreign communication by wire . . . ." "48 "Communication by wire" is defined by section 3(a) as

the transmission of writing, signs, signals, pictures, and sounds of all kinds by aid of wire, cable, or other like connection between the points of origin and reception of such transmission, including all instrumentalities, facilities, apparatus, and services (among other things, the receipt, forwarding and delivery of communications) incidental to such transmission. ${ }^{40}$

These definitions are of little assistance in defining the "common" element of a carrier or, in fact, a "carrier." The language of section 3 (h) does indicate, however, that the phrase "common carrier for hire" merely includes that entity engaged in communication by wire, that is, transmission (by virtue of section $3(\mathrm{a})$ ).

45 S. 2989, H.R. 14109, 89th Cong., 2d Sess. (1966). See note 72 infra.

46 See Irwin, supra note 39, at 1305-06, $1308-09$.

47 The first computer sold for business data processing purposes was delivered in 1954. By 1962, there were 16,187 computers installed. J. BERNSTEIN, THE Analytical Engine: Computers, Past, Present, and Future 81 (1966).

4847 U.S.C. $\$ 153(h)$ (1964).

4947 U.S.C. §153(a) (1964). 
The "carriage" concept in the communication context is "transmission," a word not defined in the Act. It is plain that, at the time of enactment, "communication by wire" was thought to include the total message service of a communications operation such as Western Union or the AT\&T general telephone service. Such operations typically included wire facilities over which messages in the form of electric impulses would travel as well as instrumentalities for the sending, directing and receiving of such messages. This is made clear by the statutory inclusion of "receipt, forwarding, and delivery of communications by wire."

In Telequote III, Bunker-Ramo furnishes facilities for the receipt and delivery of communications through input and output devices. Through the leasing arrangement with Western Union, moreover, it appears to offer its customers the transmission package of wire facilities connected to these receiving and delivery devices. The proposed Telequote IV would have added, through its message-switching capacity, the additional service of "forwarding" messages from one location to another. To some extent, therefore, Bunker-Ramo is engaged in "communication by wire." In Telequote III, such communication is only between others and itself. Bunker-Ramo is actively engaged on one side of every communication that travels over the leased wires. Telequote IV, however, offers a full communication service with respect to some messages-the facilities owned and leased by Bunker-Ramo constitute a mere conduit for these messages, the same type of service performed on a more general scale by the typical telephone or telegraph company. Thus, although the Telequote III service falls within the "communication by wire" concept, the service contemplated under Telequote IV more closely approximates the normal service of those communication "common carriers" in existence when the Communications Act was passed.

Since both services arguably fit the statutory criteria of one engaged in "communication by wire" it remains to be determined whether they should be brought within the "common carrier for hire" jurisdiction of the Communications Act. The legislative history of section $3(\mathrm{~h})$ is of little assistance. It states that:

the definition does not include any person if not a common carrier in the ordinary sense of the term, and therefore does not include press associations and other organizations engaged in the business of collecting and distributing news services which may refuse to furnish to any person service which they are capable of furnishing, and may furnish service under varying arrangements, establishing the service to be rendered, the terms under which rendered, and the charges therefor. ${ }^{50}$ 
It has been suggested that a common carrier "in the ordinary sense of the term" refers to the common law definition. ${ }^{51}$ This requires an examination of the nature of a common carrier in the transportation industries, the domain of carriage regulation prior to the advent of modern communications. At common law, "one who undertakes for hire to transport from place to place the property of others who may choose to employ him is a common carrier." 52 Certain carriers, by reason of the far-reaching importance of their business activities, were thought to have dedicated the use of their private property to the public. Having created a public interest in their activity, these carriers became subject to government protection on behalf of that interest. ${ }^{53}$ Carriage for the public at large was seen as an undertaking sufficiently important to warrant considerable public intervention. From this standpoint, it is the "for hire" element in a carriage operation which is decisive as to legal status and the other criteria sometimes said to denote the existence of a common carrier, such as the lack of power to discriminate between customers, follow only as a matter of public policy once the common carrier status is determined.

The FCC cases dealing with the common carrier concept have retained this concern for the scope of the "for hire" element of a particular communications offering, but have developed an additional interest, dictated by the nature of communications, in deciding the question of control over the specific communications involved. This reasoning has been applied to the recent group of cases dealing with the legal status of community antenna television systems. In Frontier Broadcasting Co. v. Collier, ${ }^{54}$ the Commission defined a communication common carrier as follows:

Fundamental to the concept of communications common carrier is that such a carrier holds itself out or makes a public offering to provide facilities by wire or radio whereby all members of the public who choose to employ such facilities and to compensate the carrier therefor may communicate or transmit intelligence of their own design and choosing between points on the system of that carrier and other carriers connecting with it. In other words, the carrier provides the means or ways of communication for the transmission of such intelligence as the subscriber may choose to have transmitted. The choice of the specific intelligence to be transmitted is, 1965.

51 Letter from Arnold, Fortas \& Porter to Bunker-Ramo Corporation, Mar. 12, (1927).

52 Washington ex rel. Stimson Lumber Co. v. Kuykendall, 275 U.S. 207, 211

63 See Munn v. Illinois, 94 U.S. 113, 124-36 (1876).

5416 P \& F Radio Reg. 1005 (1958). 
therefore, the sole responsibility or prerogative of the subscriber and not the carrier. ${ }^{55}$

Following this standard, the Commission held that a CATV system was not a common carrier offering because, although it offered to transmit television signals to anyone desiring to subscribe, "the specific signals received and distributed by the CATV system are, of necessity, determined by the CATV system and not the subscriber." 56

Applying these concerns to the services proposed by Bunker-Ramo, one finds that they serve partially to exempt these services from the concept of a communication common carrier. In Telequote III, Bunker-Ramo limits the communications which travel over the private lines to stock quotations and related information and there is no communication between the subscribers to the service. This is similar to the type of service discussed in Subscription Television Inquiry, ${ }^{57}$ in which the Commission said:

It has been a fundamental concept in the communications field that $a$ person is not a 'common carrier' of communications where he is providing his subscribers primarily with a news or information service, rather than with a communication service enabling subscribers to communicate among themselves. Thus for example, while the furnishing of leased wires or radio circuits by the telephone or telegraph carriers is part of their common carrier activities, the use of such leased wires by the news services to transmit news to their subscribers, or by the stock exchange to transmit price quotations has been held not to involve common carrier operations. Similarly in the case of subscription radio or television program services, the subscribing members of the public would be paying for the programs rather than for the use of the communication facilities. ${ }^{58}$

This reasoning seems to place the Telequote III offering beyond the common carrier concept and may explain the past acquiesence of the carriers in leasing lines for service. It does not appear to exempt the Telequote IV service which does provide "a communication service enabling subscribers to communicate among themselves."

55 Id. at 1008-09; accord, Industrial Radiolocation Service, 8 P \& F RADro REG. 2d 1545 (1966); WSTV, Inc. v. Fortnightly Corp., 23 P \& F RAdIo REG. 184 (1962) ; CATV and Repeater Services, 26 F.C.C. 403 (1959).

The FCC, however, has since attempted to regulate CATV systems under other provisions of the Communications Act. The question is now before the Supreme Court. See Southwestern Cable Co. v. United States, 378 F.2d 118 (9th Cir.), cert. granted, 36 U.S.L.W. 3167 (October 24, 1967).

5616 P \& F Radro REG. at 1009.

577 P \& F RADIO REG. 2d 1501 (1966).

58 Id. at 1513 (emphasis added). 


\section{The "Primary Business" Test}

Subscription Television Inquiry, however, does suggest a basis upon which to exempt both services. Paraphrasing the language from that case, this solution would define a communications "common carrier" as one who "is providing his subscribers primarily . . . with a communications service enabling subscribers to communicate among themselves." This language indicates the possibility of adopting a variant of the "primary business" test, which has been urged by Bunker-Ramo as fully exempting it from the common carrier jurisdiction of the FCC.

The "primary business" test, as it has evolved in the transportation area, necessitates gauging the extent to which a carrier provides carriage for hire in a case where some, and often most, of its carrier operations are clearly not offered for hire but are a natural part of a non-carrier business. The test is, by its very nature, one of gradations, encompassing the gamut of enterprises in which actual carriage plays a greater or lesser role in terms of income, expense or other operating criteria. It is ideally suited to one engaged in a manufacturing-type business entailing the carriage of his finished product to its point of sale. ${ }^{59}$ Such a manufacturer carries only for himself and those with whom he trades in his non-carrier business and, while he will naturally try to recoup his carriage expenditures through sale revenues, it is only by extreme reasoning that he can be said to be offering his carriage operation "for hire"-it is only an incidental portion of his total business which he feels economically compelled to perform.

While the FCC has not expressly adopted the "primary business" test, there is some indication beyond Subscription Television that it is amenable to such an approach. Analogous reasoning, which avoids the considerable financial paper work inherent in basing the test upon operating criteria, is found in Industrial Radiolocation Service, ${ }^{60}$ in which the FCC excluded from common carrier status a service which, through the use of radio waves, provided various geological and other scientific services to its subscribers. In reaching its result, the Commission said:

Central Committee indicated that the petroleum industry, as one of the principal customers of Radiolocation Service licensees, has never believed that communications service for-hire was being rendered. The Committee stated that the service received is engineering in nature and the tuse of communications facilities is incidental to this principal function. ${ }^{61}$ (1943).

69 See, e.g., L. A. Woltishek Common Carrier Application, 42 M.C.C. 193

608 P \& F RADIo REg. $2 d 1545$ (1966).

$61 \mathrm{Id}$. at 1551 . 
It should be noted that this "primary business" test serves the needs of Telequote III more than Telequote IV. While the former is in a position analogous to that of a manufacturer who transports his own goods, the latter represents the communications equivalent of a manufacturer who transports not only his own finished product but also the goods of others. In transportation, this is the problem of "return hauling" by a private carrier, ${ }^{22}$ which has been treated differently from the normal "primary business" situation. There is no reason, however, why the reasoning of the "primary business" test cannot be effectively applied to a situation like that of Telequote IV, since the objective would be the same: to free from regulation those firms which offer a communications service incidental to and intimately connected with a data processing service.

Adoption of the "primary business" test would probably be held within the competence of the FCC. In Philadelphia Television Broadcasting Co. v. FCC, ${ }^{63}$ in which the Commission's holding that CATV systems were not communications common carriers was upheld, the court said:

In approaching the problem of statutory interpretation before us, we show "great deference to the interpretation given the statute by the officers or agency charged with its administration. 'To sustain the Commission's application of this statutory term, we need not find that its construction is the only reasonable one or even that it is the result we would have reached had the question arisen in the first instance in judicial proceedings." "’

We think such deference to the agency's interpretation of its governing statute is reinforced where, as here, the legislative history is silent, or at best unhelpful, with respect to the point in question. Congress in passing the Communications Act in 1934 could not, of course, anticipate the variety and nature of methods of communication by wire or radio that would come into existence in the decades to come. In such a situation, the expert agency entrusted with the administration of a dynamic industry is entitled to latitude in coping with new developments in that industry. ${ }^{64}$

It is true that the holding was partially based on the fact that the FCC had alternative jurisdiction over CATV systems under the broadcasting sections of the Act, a fact which the court felt broadened the Commission's scope of action, ${ }^{65}$ but the lack of such alternative

62 See Red Ball Freight Co. v. ICC, 377 U.S. 311 (1965); Porter, Federal Regulation of Private Carriers, 64 HARV. L. REv. 896, 905-06 (1951).

63359 F.2d 282 (D.C. Cir. 1966).

64 Id. at $283-84$.

65 Id. at 284. 
jurisdiction should not be determinative in the instant context. Certainly, the dynamic quality of the communications industry is best shown in the case of data processing. Similarly, such rapid change was unanticipated by the 1934 legislation. The "primary business" test, in the present context, represents a reasonable effort to balance competing considerations in order to create a workable structure and should, in the absence of a clearer statutory mandate, be acceptable to the courts.

\section{Regulation of the Carriers' Data Processing Services}

Closely related to the legal status of data processing firm offerings is the data processing potential of the common carriers, which are relying increasingly upon digital computers for the automation of their communication services, ${ }^{, b}$ a potential demonstrated by Western Union's entry into the data processing field. ${ }^{67}$ Western Union has not filed tariffs for its data processing services. ${ }^{68}$ It is consistent with the above analysis that it should not be required to file such tariffs, if combined communication-data processing services are kept separate from "purer" communications services and held to the same limitations imposed on data processing firms by the "primary business" test. This solution provides for maximum competition in the data processing field consistent with the regulatory requirements of the Communications Act. It encourages separation of "mixed" carrier offerings from those clearly intended to be regulated, to the extent that it encourages a carrier to price the former as a single package. It does not, of course, prevent the more subtle means of carrier discrimination in favor of themselves.

The AT\&T system, possessing tremendous computer capacity, has not yet entered the data processing field. The explanation for this may well be a 1956 consent decree which prohibits AT\&T from "engaging . . . in any business other than the furnishing of common carrier communications services . . . or . . . businesses or services incidental to the furnishing . . . of common carrier communications services." "99 Jurisdiction over AT\&T lies with the district court. Hence, the FCC does not have the usual opportunity to pass on a specific service through the doctrine of primary jurisdiction. It is suggested, however, that the Justice Department recognize the pervasive issues involved and consider whether they might best be left to resolution by the FCC.

${ }^{60}$ Irwin, The Computer Utility: Competition or Regulation?, 76 YaLE L.J. $1299,1301-02$.

67 Western Union Telegraph Co. Prospectus, December 5, 1966, at 5, 6, 8-9.

68 See Irwin, supra note 66, at 1304. However, ITT World Communications Inc. has recently submitted a tariff covering a message-switching service. ITT World Communications Inc., Tariff FCC No. 54.

69 United States v. Western Electric Co., 1956 Trade Cas. I68,246, at 71,132 (D.N.J. 1956). 


\section{Conclusion: A Measured Response}

This Comment is based on the assumption that, given the present lack of knowledge, it is best to defer regulation of data processing firms which may well be subject to regulation by the FCC as a result of their increasing dependence on common carrier communication facilities. This assumption may be subject to dispute on formalistic grounds. There are those who contend: (1) that such data processing services have all the "earmarks" of public utilities; ${ }^{70}$ (2) that such services are clearly covered (a) by a statute which was drawn up without computer services in mind and is in many senses inadequate to deal with the problem, and (b) by carrier tariffs which were also drawn up with other situations in mind and which should present no obstacle to the public interest in development and dissemination of computer services.

Such objections appear woefully inadequate in the face of the distinct possibility that regulation at the present time might well deter entry into and development of this relatively young and competitive industry. If the message-switching services are held to entail either partial or complete regulation of data processing firms, there is a much greater possibility that the present common carriers, given their capital positions and ability to discriminate in favor of themselves, will be given effective control of the "mixed bag" of data processing services under consideration. ${ }^{71}$ This will enable them to gain substantial power in the "purer" data processing market. Those firms put to the choice of either not offering message-switching service or submitting to regulation and choosing the former course must face the distinct possibility that the carriers will undercut the private firms' position in the non-regulated market. Even partial regulation, limited to that part of the service associated with message-switching, would necessitate the separation of cost components, an extremely difficult and expensive operation when the same computer handles both services. In short, the public interest would appear to be best served by continued competition, while no such advantage can be seen, at present, to inhere to regulation of the data processing firms which will surely have sufficient problems competing with the carriers if, as has been suggested, the latter are allowed to enter the data processing market.

Adoption of the "primary business" test, on the other hand, permits the development of computer service technology to proceed in a competitive atmosphere, thereby limiting the extent to which carriers may use their present monopoly power to expand disproportionately in economic areas theoretically free from such power. It is

70 See D. Parkeill, The Challenge of the Computzr Utility 148 (1966). But see P. BARAN, THE CoMing CoMpUter UTILITY-LAISSEz-FaIRE, Licensing oR REGULATION? 8-9 (1967) ; Irwin, supra note 66, at 1313-17.

71 See text accompanying notes $38-41,43-46$ supra. 
true that this will not obviate the opportunity for carriers to price private line service so as to discriminate in favor of themselves. This problem is inherent in the wholesale nature of their operations and the danger presented, although real, does not presently seem a sufficient reason to prohibit such carriers from offering mixed services.

The "primary business" test, if implemented by the FCC, will probably require some adjustments in the current tariffs of the carriers. Such tariff modification could be applied consistently with that test if the restrictions on resale were applied only to sales to another common carrier. By virtue of the "primary business" test, restrictions on resale would apply only to those firms which merely desired to gain the economic rewards of common carriage, without the substantial investment which such status normally entails.

Another, and perhaps more satisfactory, solution to this problem would be to expand upon the legislation recently proposed by the FCC in relation to inter-carrier exchange of service operations. The proposed legislation provides, in essence, for forced inter-carrier leasing of facilities based on a "fair and reasonable" standard supplemented by considerations of "public convenience and necessity." $\mathbf{7 2}$

Applied to applications for the use of carrier facilities by data processing firms (firms presumably exempted from regulation by reason of the "primary business" test), a supplement to this proposed statute would provide:

Upon petition by a party to a contract or arrangement providing communication facilities for data processing purposes, or on its own motion, the Commission, after full opportunity for hearing, may modify or prescribe the terms and conditions

72 This legislation provides in pertinent part:

Upon petition by a party to any such contract or arrangement, or on its own motion, the Commission, after full opportunity for hearing, may modify or prescribe the terms and conditions under which the facilities described therein shall be provided if it finds that such modification or prescription is fair and reasonable, that it will not be unfairly or unreasonably discriminatory in relation to any other contract or arrangement between one of the parties and another common carrier, and that it will serve the public convenience and necessity.

(b) The Commission may, upon petition by a common carrier, and after full opportunity for hearing, order a common carrier to provide facilities for interstate or foreign communication by wire or radio to the petitioning carrier if it finds (i) that such action is in the public interest; (ii) that the carriers have been unable to agree with respect to the provision of such facilities; (iii) that the provision of such facilities will not impair the ability of the supplying carrier to perform its duty to the public; and (iv) that such facilities are reasonably available without the construction of new facilities. If the carriers involved fail to agree upon the terms and conditions under which such facilities are to be furnished, the Commission, after full opportunity for hearing, may prescribe such terms and conditions as it finds will be fair and reasonable, will not be unfairly or unreasonably discriminatory in relation to any other contract or arrangement between one of the parties and another common carrier, and will serve the public convenience and necessity.

S. 2989, H.R. 14109, 89th Cong., 2d Sess. (1966). 
under which the facilities described therein shall be provided if it finds that such modification or prescription is fair and reasonable, that it will not be unfairly or unreasonably discriminatory in relation to any other contract or arrangement between the common carrier and any other party and that it will serve the public convenience and necessity.

(b) The Commission may, upon petition by a party intending to use communication facilities for data processing purposes and after full opportunity for hearing, order a common carrier to provide facilities for interstate or foreign communication by wire or radio to the petitioning party if it finds (i) that such action is in the public interest; (ii) that the parties have been unable to agree with respect to the provision of such facilities; (iii) that the provision of such facilities will not impair the ability of the supplying carrier to perform its duty to the public; and (iv) that such facilities are reasonably available without the construction of new facilities. If the parties involved fail to agree upon the terms and conditions under which such facilities are to be furnished, the Commission, after full opportunity for hearing, may prescribe such terms and conditions as it finds will be fair and reasonable, will not be unfairly or unreasonably discriminatory in relation to any other contract or arrangement between the common carrier and any other party, and will serve the public convenience and necessity.

This statute, modeled on the inter-carrier legislation, ${ }^{\mathbf{7 3}}$ would, by supplementing the "just, fair and reasonable" standard with that of the "public convenience and necessity," substitute a licensing procedure similar to that used in the broadcasting field for the present tariff approach. Such a procedure would provide the FCC with considerable leeway to administer the licensing in the light of the requirements of particular industries or geographical areas. The Commission would be kept in constant touch with the market power of data processing firms and be able to measure any tendencies toward dangerous concentration. Such a structure would also enable the Commission to handle wasteful duplication of line facilities in the same locations, should such duplication reach serious levels. In summary, it would provide the FCC with a flexible tool giving many of the advantages of regulation without the concomitant disadvantages which full regulation would presently impose on the data processing industry.

73 See note 72, supra. 